\title{
The sacrificial sheep in three French-North African film: displacements and reappropriations
}

\author{
Dora Carpenter-Latiri \\ http://arts.brighton.ac.uk/staff/dora-carpenter-latiri
}

\begin{abstract}
In this article I will examine three films featuring Maghrebi migrant families between the 1960s and the present day, Le Gone du Chaâba (1997) by Christophe Ruggia, Inch'Allah Dimanche (2001) by Yamina Benguigui and Le Grand Voyage (2004) by Ismaël Ferroukhi. Each film portrays tensions between generations, between sexes, between societies and between beliefs and values. The tradition of the sacrifice of a sheep in Islam features in all three films and I use this theme to highlight how different members of the families sacrifice themselves or are sacrificed in the process of accommodating to a new way of life. I also deconstruct other subtextual references to Islamic culture and belief as representations of dilemmas and forms of reconciliation and belonging.
\end{abstract}

In this paper, I will explore the symbols and representations of the sacrificial sheep in three French-North African films. North-African families are represented, the characters are migrant parents and their children and the context is France with references to the country of origin: Algeria for Le Gone du Châ̂ba and Inch 'Allah Dimanche, Morocco for Le Grand Voyage. Le Grand Voyage is also a 'road movie', with other countries passed through on the car journey from the south of France to Saudi Arabia. In all three films, the father character is a North-African migrant worker. The element of class is present in the three films but although these films would be examples of the 'cinema ouvrier' - and Cadé (2004) does incorporate Le Gone du Chaâba (1997) in the filmography of French cinema representing the working class in $20^{\text {th }}$ and early $21^{\text {st }}$ century - these three films deal more with identity, transmission and belonging and could be described as 'Migration French-North African films'. The three film directors and the writer of the adapted book Le Gone du Chaâba have a personal story of migration from North Africa to France. These three films also depict Islamic rituals and references and are to be considered as examples of representations of Islam in French cinema (Higbee 2013). 
In my analysis of these three films, I will concentrate on the Islamic references and representations of the 'sacrificial sheep' (agneau du sacrifice). The sacrifice of the sheep occurs as a motif in the film Le Gone du Châ̂ba (1997) adapted from Azouz Begag's novel with the same title (1986). It is an important element in Inch'Allah Dimanche by Yamina Benguigui (2001) and a recurring motif in Le Grand Voyage by Ismaël Ferroukhi (2004). In Le Gone du Chaâba - novel and film adaptation - and Inch'Allah dimanche, the sheep is part of the ritual of the celebration, the fête du mouton, translating literally as 'the feast of the sheep'. Eid Al Adha, literally 'the feast of the sacrifice' is the formal Arabic name of the Islamic annual feast commemorating Ibrahim's willingness to sacrifice his son to God: in the Islamic calendar the celebration of Eid al Adha corresponds to the time of the Hajj. In the third film Le Grand Voyage, the sheep is associated with the pilgrimage to Mecca in which the commemoration of the story of Abraham - or Ibrahim - (and often the sacrifice of the sheep) is part of the pilgrimage ritual.

I will try here to deconstruct the narrative function of the motif of the sacrificial sheep in my corpus before exploring the emerging specific signifiés of the rite of sacrifice in these representations.

\section{The story of Abraham; the Eid al Adha ritual and its meanings}

The story of Abraham is commemorated in the Quran; the narrative is similar to the story of Abraham and Isaac as told in the Bible, although in the Quranic text the son is not named (Quran XXXVII 99 - 111. For a comparison with the Old Testament account, cf. also Dioceserabat.org, 2014). In the Islamic tradition however, the son Abraham is bidden in a dream to sacrifice is his first son Ismail (Ishmael to use the usual English Bible spelling). God then intervenes and sends the archangel Gabriel so that a ram is sacrificed and not the son.

For Muslims the ritual of sacrifice commemorates the sacrifice of Abraham - the sacrifice of a ram - but also the repetition of the sacrifice of Abraham by the prophet Mohamed. The ritual with its references to both Mohamed and Abraham is performed during the Eid celebration. It is not one of the pillars of Islam, but it is performed as part of the final stages in the Hajj, the fifth pillar (Cf. Brisebarre 1998, 2003, p 10). The Eid is called Eid al Adha, literally, the celebration of the sacrifice. In the Maghreb it is also called Eid al Kebir, the 'great celebration' which stresses its special importance, by contrast with Eid al Fitr, the Eid that celebrates the end of the fasting month of Ramadan which is called Eid al Seghir, the small Eid.

The Islamic tradition traces the sacrifice back to both the patriarch Abraham as the founder of the monotheistic tradition and to the prophet Mohamed who reinstated the 
monotheistic tradition for the Arab people and performed the ritual of the sacrifice of the sheep himself. The Abrahamic lineage is an important element for establishing a connection between Islam, Judaism and Christianity: in the Islamic tradition, Muslim, Christians and Jews are also united in the expression 'People of the Book'. In Auf der anderen Seite (The Edge of Heaven), another migration film representing a Turkish father and his son in Germany, this element of connection between Islam and the West was explicitly highlighted. This powerful film by Turkish-German director Fatih Akin, a cross-cultural/cross generation tale of loss, mourning and forgiveness, won the award for best screenplay at the $60^{\text {th }}$ Cannes Film Festival in 2007. The German character played by Hanna Schygulla is at the window in Istanbul when she hears the call to prayer and sees men on their way to the mosque; the main Turkish male character played by Baki Davrak explains that it is 'Bayram', the feast of sacrifice, and tells the story of Abraham. The German character replies 'we have the same story'.

The sacrifice of the sheep in the Islamic way of life, and more specifically in the Maghreb is not only religious, it also reaffirms family and social bonds within the community (Cf. Kanafani-Zahar, 1997, pp. 83-100, describing the different stages surrounding the ritual in Lebanon, similar to those in Maghrebi societies). Food is shared and a part of the meat is given to the poor. Finding the sheep, looking after it and preparing it for the festival involves all the generations, the neighbourhood and other social networks. The sheep itself is perceived as a blessing and everything around it also brings blessings. The preparation and sharing of the sacrificed sheep involves a wider community than the one involved in an ordinary shared meal, as the whole of the sheep carries the blessing and must be processed: sausage making, curing the meat, tanning the skin, washing the wool, etc., require many skills but allow the broader community to participate. The blood however is taboo but protective: one Maghrebi tradition is to dip the hand in the blood and to mark a wall or the house door with it to show that the sacrifice has been performed, often with the addition of the traditional protection of the hand, the khomsa. The sacrifice is strongly connected with distribution and the involvement of the broader community at different levels. In migration, the ritual loses the component of visibility in the community space, as - in accordance with French regulations - the sacrifice must take place in slaughterhouses, in a designated space that is more compatible with French health and safety regulations and which would not transgress ordinary French routine or offend animal rights organizations.

In the context of migration, away from the shared values of the community, and in a space that does not allow the celebration of the sacrifice of the sheep to be displayed in the same way (something now true for many living in urban areas in Muslim countries); the Eid ritual in migration is performed differently from the Eid ritual in the Maghreb (Brisbarre, 1998); similarly the narratives of the Eid in migration cinema will be invested with new meanings and new symbolisms as they translate the experiences of the migrant 
as well as reach out to a culturally diverse audience in France, predominantly nonMuslim. The French-North-African audience would not necessarily identify with the religious elements but would be familiar with the cultural references to migration and to Islam.

In the three narratives that I analyse here, there are different degrees in the transformation and reinvention of the Eid. The three narratives present Maghrebi families that settled in France during the $60 \mathrm{~s}$ and $70 \mathrm{~s}$ at the time of the so-called regroupement familial where migrant fathers had been authorized by the French authorities to bring over and raise their families in France. The context of the narratives is also the 60s and 70s for Le Gone du Châ̂ba and Inch'Allah dimanche, while the narrative context of Le Grand Voyage is the present day (mid-2000s), many years after the time of that regroupement. The 'family' component in the narratives allows for a natural insertion of the Islamic calendar of celebrations in the narratives; in the case of Le Gone du Chaâba and Inch 'Allah dimanche, the focus is on the Eid, in the case of Le Grand Voyage, the focus is on the Hajj - the pilgrimage to Mecca - which in the Islamic calendar coincides with the Eid in the final stages of the pilgrimage rituals.

\section{Analysis of the narratives with a focus on the sheep motif and its association with the migrant parent}

\section{Le Gone du Chaâba}

Le Gone du Chaâba, translated into English as "Shantytown Kid", is an autobiographical novel by Azouz Begag about his life as a young Algerian boy growing up in the 1960s in a shantytown near Lyon, France, called the Chaâba by its inhabitants. The film adaptation earned the director Christophe Ruggia - born in France to a pied-noir father - a César nomination for Best Debut. 'Gone' is the word for 'kid' in Lyon slang. In Begag's autobiographical story, the narrative is told by the son, Azouz. The novel is an autobiography and a Bildungsroman, where the main character - the narrator - and the author are the same; the name of the main character is the same as the author's: 'Azouz Begag'. The celebration of the Eid (Eid Al Adha) is taking place on the same day as his circumcision, which adds another religious dimension to the ritual itself. The film narration follows the same structure as the book and keeps to the autobiographical style: the director's use of the camera is subjective showing what the main character (Omar, in the film) sees and sharing it with the audience. In the film le Gone du Chaâba however, the sheep is not explicitly associated with the Eid, this element is available to the audience through cultural knowledge: the celebratory event in the film narrative focuses on the little boy's circumcision although there is also the information that the circumcision is performed on the very day of the Eid. The circumcision is constructed and presented explicitly as a sacrifice for becoming a man and following the rules of Islam. As for the Eid, it is still represented as the important Islamic celebration which 
traditionally involves the whole community: in the film the whole Chaâba community is involved but the celebration concentrates on the circumcision. It is Omar's father, Bouzid, interpreted by Algerian comedian, writer, humorist and actor Mohamed Fellag, who is in charge of this initiation ritual: he is the one who communicates the symbolic meanings of the circumcision/rite of passage to the little boy and to the audience. There is an ellipsis in the film about the Eid itself as the film focuses on the performance and celebration of the circumcision, although the sacrifice of the sheep is suggested as the celebration of the circumcision is organized by Omar's father and his brother, Said, who runs an illegal butchery in the shantytown. The circumcision is for Omar and his cousin/best friend Hacène, the son of Said, Bouzid's brother, the Chaâba butcher.

In the film, it is only through the important sub-plot of the illegal butchery that we see close-ups of the slaughtered sheep in the shack that Said uses for his trade: there is no slaughtered sheep for the audience to see in the circumcision/Eid celebration episode. Said has an ambivalent role: on the one hand, as he is better off than Bouzid, he puts up the money for the circumcision; on the other, his business is illegal and threatens the whole Chaâba community. Through the gaze of the little boy we see the conflict between the two fathers: Bouzid and Said. In the film, the cluster of meanings of la fête du mouton ('the Eid of the sheep') is split and re-constructed: the Eid features are concentrated on the feature of the celebration (Islamic, festive, with presence of the community), which itself merges with the celebration of the circumcision. The sheep (a key feature of the Eid al Adha) is present indirectly but not visually represented and the highlighted sacrificial dimension refers to the circumcision whilst the sacrifice of the sheep itself is somehow sacrificed. This sacrificial dimension binds the little boy to his father as he is now 'a man' thanks to the debt contracted by his father for this initiation. The debt is a condensation of the many sacrifices endured by the father, as later on in the film Omar sees for himself the hard physical labour his father does for a living and makes the promise to himself, addressed at this father, that he will be the best: 'Je serai le meilleur Abboué, meilleur que les Français, meilleur que tout le monde, je te le promets'. The absence of the sheep - not represented in the circumcision celebration - reinforces an emphasis on the symbolic meanings of the sacrifice. What is sacrificed is childhood (Omar becomes a man after the performance of his circumcision) and the old ways: after Omar innocently leads the authorities to the illegal butchery, Bouzid is afraid of being expelled from France and throws his brother out of the Châ̂ba, unleashing his anger and frustration demolishing the butcher's shack. Alongside Omar's growing awareness of the sacrifices of his father, the character of the father is suggested as a sacrificial victim in this narrative of migration and belonging. The father is sacrificed not only because his life is hard but also because - as he embraces life in France - he has to let go of his old village ways, something his cousin Said (the butcher) is unable to do. This sacrifice illustrates the loss of power of the migrant father and is often represented in French-North African fiction - for example: Le Thé au harem d'Archimède, Mehdi Charef's book 
(1983) and its film adaptation (1985); La Graine et le mulet, by Abdellatif Kechiche (2007), and in documentary cinema - for example: Perdus entre deux rives, les Chibanis oubliés, by Rachid Ouidi (2014). The rewards for Bouzid 's sacrifices are Omar's (Azouz's) success at school and later in life, while the failure of Hacène, who performs poorly at school and - in demanding protection money from prostitutes - shows signs of delinquency in the future, is indirectly connected to Said's inability to accept the rules of the French way of life. The ellipsis on the sacrifice of the sheep with the shift to the circumcision and its Islamic meanings suggests that Islam in migration should leave some of the old ways behind and be redefined with a focus on the symbolic rather than the literal interpretations. The literal aspect is here represented by Said, the butcher, with Hacène's story unfolding as an alternative story to Omar's success story. Hacène is Omar's cousin and best friend: the difference between the two lies in their fathers' different sacrifices: in holding on to the old village ways indiscriminately, Said does in fact sacrifice his own son Hacène, whilst Bouzid sacrifices himself and some of his old ways, those he perceives as unsuitable for life in France. The narrative (in both film and book) argues in favour of a selective re-interpretation of Islam for the survival ('intégration') of the second generation in France and is an artistic representation of the ongoing debates and initiatives about 'I'Islam dans la République' in French media and official discourse.

The circumcision with its explicit performance in the film is kept to emphasize that the Islamic identity is redefined but not rejected. Loyalty to the community and the celebration of what binds it is kept through the memory of the Chaâba long after its members have been relocated in apartment blocks; this memory as well as loyalty to the community is one of the purposes of Begag's narrative in book and film. The story covers a period of approximately three years in the life of Azouz/Omar and is often characterized as dealing with issues of the clash of two cultures, or of the difficulties of finding a cultural identity between French and North African cultures: 'Azouz Begag's Le Gone du Chaâba (1986), not only develops the hybrid beur subject as such, but also moves towards resolving the we/they schism by reclaiming a conciliatory voice for him within the French narrative.' (Emery, 2004 p.1152). ('Beur' is the colloquial term to designate French-born people whose parents or grandparents are immigrants from North Africa.)

Before we reached the feast of the sacrifice/circumcision in film and novel narrative, the sheep motif in the story was first approached as a lead to the illegal slaughterhouse run by the uncle in the shanty town where the extended family was living in much the same way as they would in their Algerian village. The slaughterhouse leads to a confrontation with the local authorities, and to the little Azouz/Omar helping the French authorities discover the 'illegal slaughterhouse': this sub-plot uses the motif of the sheep to position the little boy on the side of French law. In this part of the story his father is aware that the 
slaughterhouse run by the uncle is illegal and condemns it, so there is no conflict between father and son. The whole narrative stresses the transformation of the character of the son with the encouragements of the father. This transformation is part of the structure of such a story which is a roman d'apprentissage, a Bildungsroman, as the story could be summarized as the transformation of a little boy who had nothing into an author, a scholar, etc., thanks to the miracle of French schooling, or metonymically thanks to the miracle of the book. The transformation of Omar/Azouz through the book trope carries strong Islamic connotations: in the Islamic tradition, the miracle that allows Mohamed to stand as a prophet is that he can 'read'.

When we reach the feast of the sacrifice in the narrative, there is an accumulation of signs around this trope of the 'book'. In the film there is even an elliptic convergence which brings all together the sacrifice of the sheep, the circumcision and the book: just after the circumcision, Omar is carried to bed and his father gives him a book (Vingt mille lieues sous les mers by Jules Verne) that consoles him straight away. The book has the power to appease and enchant the boy; it heals the pain of the circumcision and transforms the Islamic rite of passage into an initiation to a larger world. The world of men that the boy enters with the circumcision becomes also the world of books. The book is strongly polysemic, in association with Islam and as a reward for the circumcision, it refers indirectly to the Quran and it connects the little boy to his Algerian-Islamic roots; the book is also the metonym for the French school system and the successful transformation it allows. Finally the book also symbolises the bridge between cultures, as in the Islamic tradition, the Christian other encountered in migration is part of the Abrahamic monotheist tradition also called 'the People of the Book' (Ahl al kitab).

The condensation of these elements (Eid, circumcision, book) in the film stresses the connection between the theme of the sacrifice (bringing together the circumcision and the sacrifice of the sheep) and the integration into French society through knowledge. In the narrative, a passage shows the discovery of a dictionary in the dump, which is also the playground of the shantytown kids. Dust and mud are ever-present in both text and film with the suggested Islamic figure of the creation of the first man, dust and clay (and water and blood), mentioned in the Quran in the creation of man. In the narrative, there is a feeling of happy ending as Azouz Begag embodies a Maghrebi migration success story: at the end of the film the audience is told through a final slide that Omar is Azouz Begag and that he became a researcher and a writer: 'Dans la vie Omar s'appelle Azouz Begag. Le film est adapté de son roman autobiographique 'Le Gone du Chaâba'. Aujourd'hui Azouz Begag est chercheur au CNRS et écrivain.' The facilitator for Azouz-Omar's successful integration is the character of the father who as a pioneer in the migration of his family opens a new chapter for his son in encouraging him to embrace French education. The father is depicted as a primitive character, sometimes brutal, often naïve and ignorant - but as the migrant father, he is the one who opens the way for the 
transformation of his son. The feast of sacrifice and the circumcision embedded in it are the traditions transmitted by the father that will allow the son to connect to a broader Abrahamic heritage and to belong.

\section{Inch'Allah dimanche}

Inch 'Allah dimanche by Yamina Benguigui (2001) is a fiction that tells the story of Zouina, who comes to France -with her children and dreaded mother in law - to be reunited with her husband, an Algerian migrant worker. Benguigui was born in Lille to migrant Algerian parents and her film draws on childhood memories. The story takes place in 1974, during the years of the regroupement familial when the French government allowed Maghrebi migrant workers to bring their family to France and focusses on the migrant's wife. The film opens with three silent slides explaining what the 'regroupement familial' is and providing historical context to the fictional story.

Au lendemain de la seconde guerre mondiale, la France manque de maind'œuvre. Le gouvernement recrute massivement des maghrébins, en particulier des Algériens. La loi ne les autorise pas à faire venir leur famille. Commence alors une migration d'hommes seuls. En 1974, le gouvernement Chirac veut mettre un terme à toute nouvelle immigration. Les épouses et les enfants sont autorisés à rejoindre les maris et les pères, c'est ce qu'on appelle le "regroupement familial".

The point of view is feminist and carries implicit echoes from the 1970's newly born French feminist movement with the symbolic commemoration of 'the wife of unknown soldier' (Ina.fr, n.d.) . One of the feminist slogans then was 'Il y a plus inconnu que le soldat inconnu, sa femme' ('More unknown than the unknown soldier: his wife'). It could be said that Benguigui's transposes this into the situation of the Maghrebi migrant with the implicit subtext that the most isolated amongst the migrants is the migrant's wife.

In Benguigui's film, the central character is the wife Zouina and the narrative is told from her point of view. The audience watches her journey from her departure from Algiers with her children and mother-in law, her arrival in France and her awkward reunion with her husband, her submission to her husband and mother-in law to her progressive transformation and empowerment in the new country. The angle is feminist as in 'for Zouina's rights': the empathy with Zouina is built up with the audience witnessing her bullying by her mother-in law and the abuse she receives from her husband. In this narrative, as in Begag's narrative, the migratory project to give a better future to the children - specifically through French schooling - is emphasized but it will take the length of the film for Zouina to embrace it actively. The film ends with Zouina's words 'Demain, c'est moi, je vous amène à l'école', 'Tomorrow it's me, I'm taking you to 
school' (the French is grammatically incorrect and shows a direct transfer from the Arabic), claiming a freedom a movement for herself and a dynamic involvement in the migratory family project initiated by her husband; when the family arrives in France, the father has already bought school supplies for the children which illustrates what his migratory project is and that he is clear and active about it. As for Zouina, she started her migration journey only to follow her husband's wishes. She is almost forced to leave Algiers, she cries and runs back to her mother - who is left behind - before being pulled back brutally by the mother-in law who is travelling with her and the three children. The focus is on Zouina and the story follows her transformation and how she becomes the force that will transform the whole family, husband included.

As in Begag's narrative, the trope of the sheep and the symbolism of sacrifice are strongly present, with a different construction and new meanings. Benguigui's narrative is constructed around the sub-quest of the father for the sacrificial sheep "le mouton de l'Aïd': on the Sundays before Eid, Zouina's husband, the migrant father, goes with his mother (Zouina's mother-in law) to search for the Eid sheep. Zouina is left alone with her children and indirectly finds the space to define herself (Carpenter-Latiri, 2003). The section dealing with the sheep is at the centre of the narrative as the quest for the sheep for Eid is what provides the story with a dynamic in the narrative. The father and the mother-in law leave every Sunday to find the perfect sheep, and Zouina starts her own secret quest to find herself another migrant Algerian woman to celebrate the feast with (Malika's character, wonderfully played by Tunisian singer and actress Amina). The father needs a sheep to perform the Eid ritual and Zouina needs a friend: 'Avec qui on va les manger les gateaux de l'aïd?' ('Who are we going to eat the Eid cakes with?). The mention of the Eid cakes allows for an agreeable representation of the ritual for the Western audience but is somehow surprising for a Maghrebi audience: there are indeed cakes for Eid, but cakes are for 'the little Eid', the Eid that ends the fasting of Ramadan, not Eid al Adha. Somehow, as in the film Le Gone du Chaâba, the slaughtering of the sheep which is part of the ritual is eliminated from the narration: we do see a sheep in Benguigui's film, and we do see blood, but the blood we see is Zouina's, when she injures her hand in banging on Malika's window.

Here the sheep is the object of the quest (for the feast) and also the catalyst for Zouina's new freedom. The sheep symbolises sacrifices and also transformation. Malika, the other Algerian migrant woman in the film, is constructed as a negative double of Zouina: in opposition and contrast to what leads gradually to the new Zouina. Malika is portrayed as a trapped woman, in her home, in her submission to tradition, and in her 'myth of return', the belief shared by migrants that they will return to their country and which prevents them from settling and adjusting in their new country. Malika's submission to tradition is illustrated by her statements about what is right, for example that she is relieved her daughter is getting married to a cousin in a marriage arranged by her father. ('ça y est, je 
suis tranquille, son père il l'a mariée à un cousin'); her belief in the myth of return is illustrated by the cardboard boxes and suitcases in the tiny flat which make Zouina imagine that Malika has just arrived. To her surprise, Malika tells her she has been living in France for fifteen years. Malika's submission is also illustrated by her disgust when Zouina attempts to talk about French women and sexuality on French radio programs culminating with her throwing Zouina out of her home when Zouina reveals that she came 'en cachette de son mari'(without her husband's knowledge). Malika's entrapment in a neither-here-nor-there space warns Zouina about what would become of her if she fails to embrace change: Zouina and Malika are constructed as two polar opposites in the film paradigm of female representations. The French female character Nicole, Zouina's neighbour, is another female representation in the film that makes it possible to illustrate Zouina's complex position and the dynamics of her journey: at an earlier stage in the film, Zouina is befriended by Nicole but hides her gifts (make-up, perfume) which show that she shares the same desires as French women; when found out Zouina is beaten by her husband. With Nicole's make-up was also hidden a book about Algeria given by another French woman in the film, Mme Manant, the widow of a French officer who died in Algeria. The episode of the book allows us to find out that Zouina can read but that her husband, Ahmed, cannot. Ahmed tears the book apart and shows a complex ambivalence towards this symbol of knowledge that he cannot control, which of course is symbolic of the correlation between knowledge and (women's) emancipation. When Nicole tells Zouina 'ton corps t'appartient' ('your body belongs to you') and when she invites her to go out with her, Zouina replies 'c' est pêché' ('it's a sin'). The similarities, contrasts, and oppositions in this paradigm of female representations highlight that Zouina at the beginning of her journey is still too Muslim/Algerian for Nicole but already too French when towards the end of the film she meets Malika who throws her out. A very strong scene in the film shows Zouina banging on the glass window of Malika's flat, cutting her hand and bleeding. The juxtaposition of the blood scene with the arrival of the sheep for the feast of the sacrifice, announces the transformation of Zouina within the symbolism of the sacrifice of Abraham: she will live, it is the sheep that will be sacrificed. As in Le Gone du Chaâba, the migrant father has to sacrifice the old ways. Zouina's sacrifices are represented in her separation from her mother, Algeria and her extended family at the beginning of the film and in her nostalgic and unsuccessful quest for a new migrant friend: 'Avec qui on va les manger les gateaux de l'aïd?'. When the film ends with Zouina announcing that from now on she is the one who will take her children to school, this summarizes Zouina's commitment to a migrant's project similar to the one told in Begag's narrative and connects her to the figure of the sacrificed migrant parent.

Zouina's blood emphasizes her sacrifice and her transformation: it will also trigger her husband's emancipation from the grip of his mother: it is in this last scene that he stands up to his mother and becomes a man, Zouina's man. The school trope here, as in her words 'Demain, c'est moi je vous emmène à l'école', incorporates elements of feminist 
empowerment: freedom of movement and an end to the era of submission to the husband or mother-in-law. The film refers implicitly to the anthropological analysis of Algerian patriarchal society exploring the domineering role of mothers of boys who are also part of the system of women's oppression (Lacoste-Dujardin, 1985). Sacrificed with the sheep are the old ways encapsulated in the mother-in-law character; also sacrificed is the lethal alternative seen in the other female migrant character, Malika, whose submission to these 'old ways' leads her to a depression bordering on madness behind her closed door in a scene not witnessed by Zouina, but shown to the audience. Zouina's blood accelerates the eviction of the mother-in-law character, who - in the basic structure of the narrative - is like a wicked stepmother in a fairy tale. It must be stressed that there was some poetic licence in the incorporation of the stepmother character in the script: the regroupement familial only allowed for the spouse and the children to be reunited with the migrant parent. Benguigui's intention is to plead the case of the migrant's wife and also to denounce the patterns of alienation Maghrebi migrants carry with them. We can see Zouina taking greater agency in her relationship with her husband and her children; we can also see Zouina and her husband freed from the control of the mother-in-law. The narrative provides happy-ending elements with another fairy-tale character: the bus driver, interpreted by Jalil Lespert, a sort of Prince charming who opens the door to a new way of life in offering to the husband a model to follow and a threat (as a representative of French authority, he symbolizes a chivalrous protection of Zouina's rights in French soil). Jalil Lespert, a well-known French actor born to a pied-noir father and an Algerian mother, whose first name is Arab and family name French, lends his mixed ethnicity as a model of transformation/integration to Ahmed, the disoriented migrant father. In this film, the migrant wife is empowered through the sacrifices of the old ways (the husband's and the wicked stepmother's). The husband's transformation leads to new possibilities for the migrant couple. The fairy-tale elements simplify the narrative, repress Zouina's nostalgia and longing for friendship and give a rosy picture of French masculinity and women's empowerment.

\section{Le Grand Voyage}

Le Grand Voyage (Ismael Ferroukhi, 2004) is a road movie that takes Moroccan-French father and son - the father holds a Moroccan passport, the son a French passport - on a long car journey from their home in southern France across Italy, Bulgaria, Serbia, Turkey, Syria, Jordan to eventually arrive at Mecca in Saudi Arabia, where the father will perform the rites of the hajj pilgrimage. Ferroukhi is French-Moroccan; he was born in Morocco and grew up in the south of France. The story begins when Reda, the son, a few weeks away from his important Bac exam, finds himself forced to drive his father to Mecca after his older brother loses his licence in a drunken incident and can no longer do so. Reda is a reluctant traveller who resents having to give up his education and angry at being forced to be away from his girlfriend from school, Lisa, a relationship his family 
knows nothing about. The father is cold and distant, an old-fashioned authoritarian anxious to reach Mecca in time and unable to share his son's curiosity for the lands they cross. As the journey progresses, the father, the son and their relationship all change: the relationship is tense and sometimes brutal but they eventually learn to accept each other. The name of the son 'Reda' (in Arabic 'peaceful acceptance') summarizes the symbolic dimension of their journey. This narrative of mutual acceptance and bonding between father and son also incorporates sub-narratives of sacrifice that - as in the two other films - refer to the Abrahamic sacrifice with associated symbolic elements of transformation and transmission. Compared to the two other films for this study, Ferroukhi's film is more complex: the narrative is multi-layered and polysemic with multiple religious references and symbols.

Higbee (2013, p. 166) argues that the film suggests 'the potential conflict between Islam and (French) state as well as the clash of attitudes and priorities between the first generation (Muslim) migrant and his westernized agnostic son'. This might well be the case but the film allows also for other possible interpretations, for example that the father-and-son conflicts could be translated into the inner tensions within Islam itself. The structure of the narrative allows for this interpretation: at the end of the story, the father dies and the journey of the son will carry on with a re-appropriation of Islam. This Islamic 'acceptance' is encapsulated in two significant elements closing the film: Reda's zakat and the Sufi poem of Ibn Arabi as background soundtrack. As Reda is about to leave Mecca, we see him performing 'zakat', a pillar of Islam, giving alms to a beggar and symbolically making peace with that aspect of his father's Islam, and reconciling himself with an Islamic heritage which he will redefine for himself. This re-appropriation of Islam does not necessarily mean that Reda becomes religious but that he accepts the Islamic component in his heritage and his identity. Reda's journey can be defined as a deep inner transformation as before the final zakat scene, when father and son were crossing Syria, Reda violently resented the money his father gave to a woman beggar (his father's zakat), he grabbed the money back from her and got smacked in the face by his father. That scene culminated in the decision for father and son to separate as soon as they reached their destination, Mecca. The film also ends with a close-up of Reda's face in a taxi with in the background Moroccan singer Amina Alaoui interpreting Ibn Arabi's poem 'I believe in the religion of love', a hymn to tolerance, compassion and openness and a reference to Andalusia, the iconic and mythical multi-faith paradise. This last scene with its reference to the $12^{\text {th }}$ century Arab-Andalusian Sufi mystic highlights discreetly the direction Reda the main character - and the film - will follow. This is about making peace with the father, respecting his beliefs and acknowledging his heritage, without necessarily becoming religious. It is only in the credits that a lead to deciphering the song is to be found, echoing Reda's journey in his quest for the meaning he will give to his life. There will be no ready answers. This is about tolerance, otherness and living together. When Reda drives his father closer to Mecca, they drive under the massive 
monument at the entrance of the holy city representing a giant bookstand holding an open Quran. That shot might be interpreted as a tribute to Islam, to the Quran and to the kingdom of Saudi Arabia, guardian of the Muslim holy sites (Ferroukhi's film is the first feature film shot inside Mecca and he was granted permission to film by the Saudi authorities) but another interpretation could be that it is a metaphor about the disproportionate authority of the Holy Book over the individual. The connection between the Book and books as a metonym for schooling and 'integration' that I highlighted in the two other films is put aside in this narrative to be redefined. Of course this is a road movie and the French context is only present in the background, but early in the film Ferroukhi's characters seem to have taken in that social integration through French schools is yet another migrants' myth as demonstrated in research on ethnic segregation in French schools (see Felouzis, 2003, pp. 413-447). When Reda pleads that he cannot leave school, the argument carries little weight with either his mother or his father: the priority is for the father to accomplish his pilgrimage. In comparison to the Le Gone du Chaâba or to Inch'Allah dimanche, the belief that the way - in France or in life - will be through The Book /books/schooling is somehow put into another perspective. It is knowledge (a deeper concept than 'books, etc.' as it de-fetishizes the object) and more importantly self-knowledge that will define Reda's journey. Higbee (2013 p 166) argues that 'Réda is excluded from the community of the pilgrims by his status as a nonpractising Muslim (...), Réda retreats to the other side of the sand dune to trace the name of his girlfriend (Lisa) into the sand, emphasizing his isolation from the extended Muslim community', but I would like to argue for another interpretation. I will first emphasize the convergence between Reda's love for Lisa, his father's knowledge and acceptance of it shown in the display of the lost photo that the father places on the steering wheel - and how Reda will re-appropriate Islam and accept it as part of his identity. The name 'Lisa' is very close to the visual form of the imperative 'lis' (French for 'read') that translates the first revelation to prophet Mohamed, the angel Gabriel's injunction for Mohamed to read: '(Muhammad), read in the name of your Lord who created (all things)' (Surah 96:1). Lisa is also an allegory of France, a young and beautiful face of France, a France in love with a French-Maghrebi young man, a positive representation of the future for Reda at peace with his French-Moroccan identity. As for Reda's isolation, he is much younger than the other pilgrims that the father joins, and they accept his non-religious practices as a matter of fact while they praise him for driving his father to Mecca. It is hinted that Reda's lack of Islamic practice comes from his father not transmitting it, just as it is hinted that the drunken behaviour of Ralil - Reda's eldest brother- might be a repetition of a behaviour the father might have indulged in his younger years. Indeed the urgency for the father to perform his pilgrimage might be his feeling that it is his last chance for redemption: this redemption might explain why it is only when Reda calls for a God of forgiveness that father and son can begin to accept each other. 
When the other pilgrims praise Reda for driving his father, the father acknowledges it too and expresses joy and gratefulness towards Reda, that moment in the film seals the reconciliation and the transmission between father and son, both say to each other that they have learnt a lot on this journey and Reda - for the first time - replies in Arabic to his father, suggesting - in that context of reconciliation in Mecca - that Reda is embracing the Arabic-Islamic component (cultural, not necessarily religious) of his complex identity. Higbee highlights Reda's 'isolation': Reda is indeed isolated, but the tracing of 'Lis(a)', s name in the sand gives this isolation the meaning of a pause, a retreat, that will allow him to find himself. According to Islamic tradition, the revelations came to prophet Mohamed after his retreats in the Hira cave, near Mecca, and the first one was the injunction to read. Implicit Islamic references allow for another layer to unfold.

As in the two other films in this study, the motif of the sacrificial sheep is present in the film explicitly and symbolically. The commemoration of Abraham's gesture is embedded in the pilgrimage to Mecca: part of the performance of the hajj includes the sacrifice of an animal ('this may be a sheep or $1 / 7^{\text {th }}$ share of a camel or cow': Hashmi and Malik, 2010), the sacrifice of an animal is not compulsory for the hajj to be completed, although the prophet Mohamed's commemoration of the sacrifice of Abraham made the sacrifice an important part of the ritual. Hajj is the fifth pillar of Islam; it is required of Muslims once in their life, if they are able to perform it. The Islamic description of the hajj and of the sacrifice introduces certain elements of flexibility in the interpretation of this Islamic duty and establishes from the very beginning a possible shift from the literal repetition of Abraham/Mohamed's gesture to a symbolic appropriation. Perhaps the whole film could be analysed as a journey of symbolic appropriation, a re-reading of Islam as suggested by the episode with Mustafa in Istanbul who introduces Reda to Sufi teachings and to a more open way of practising Islam with the injunction 'tu as beaucoup à apprendre sur la religion' (you have a lot to learn about religion). Interestingly Mustafa is Muslim but non-Arab; he is constructed as a possible model for Reda: in France Sufism is sometimes represented as an acceptable form of Islam, for example in book, play and film Monsieur Ibrahim et les fleurs du Coran.

Abraham's story starts with Abraham's dream about what God would request from him, the story allows the interpretation that the dream is an illusion that would be telling more about Abraham at that moment than about God. The divine intervention replacing the son with a ram tells the value of human life; the evocation of the sacrifice in the Quran insists on requiring that it is be a gift of piety, not a blood offering: 'It is not their meat nor their blood that reaches Allah: it is your piety that reaches Him' (Surah 22:37)

In this road movie, the father's transformation carries also multiple layers of implicit references to the Quranic and Islamic tradition; the whole narrative is constructed to allow a highlight on this shift between a literal practice of Islam (as represented by the 
father in the different stages of the journey until they reach Jordan) to a deeper spiritual journey of piety (when the father is challenged by the son to be able to forgive, after the son gets drunk and flirts with a cabaret dancer near their hotel room in Amman). The father moves from the arithmetic of ticking off a sort of good deeds list that makes him feel like a 'good' Muslim into a more spiritual Sufi-like Muslim acceptance (for example in no longer being judgemental of his son). On the son's side, the transformation is achieved through his understanding and acceptance of his Muslim heritage and the resolution of his repressed identity issues (represented by his relation to the French girlfriend Lisa, now accepted by his father and that can now be in the open). The issue of the parent's generation suffering in migration which was constructed as a sacrifice and symbolized with references to the sacrificial sheep in the Le Gone du Chaâba and in Inch 'Allah Dimanche is constructed differently in Ferroukhi's film. The suffering of the parents' generation is given as a premise in the narrative: the film does not linger on this, but deals with another more pressing issue: the next generation. How will they deal with their identity? What kind of Islam will they be able to live with? Somehow the lament about the sacrifices suffered by the older generation is itself sacrificed: now, what about the young ones? Again the choice of names is revealing: Ralil (or 'Khalil' in another spelling), the elder brother who was the chosen one before he is replaced by Reda, is another name for the patriarch Abraham, known as Khalil-Allah in the Quran, sometimes translated as 'God's friend' or 'God's most intimate friend'. The fact that Ralil is left aside and that we are introduced to him as a stereotype of the Maghrebi eldest brother, i.e. a double of the father, here not only authoritarian but also a bully, reinforces the intention for the film to prioritize the second generation.

These layers of religious and symbolic meanings build up meaning as the film reaches its end. Watching it again after these meanings have been elicited, we find that from early on in the film there are many symbols and metaphors already embedded, such as the blue car with an orange door, that guzzles a lot of oil and whose first gear has a problem but that works like clockwork otherwise. The orange door is a metaphor for hybridity, the guzzling of oil is a classic hint on Arab way of life, and the difficult first gear that should not be held too long is a metaphor for the older generation. The message is that it is for the younger generation to move on and to invent their functioning hybridity rather than cloning the first generation in a dead-end pattern as displayed by the eldest brother Ralil and his suggested split identity troubles ('après (La Mecque) j'arrête de boire et je me mets à la prière Inch 'Allah' 'after (Mecca) I give up drink and start praying Insh'Allah') which triggered Reda's impatience and sudden departure from the scrapyard in one of the early scenes.

Ferroukhi's film also uses the sheep as an explicit motif in the story and it appears in three scenes. The first time, the son's camera is exchanged for a sheep so that the father can slaughter it to provide the meat that the son craves. The scene is a comic one as the 
sheep escapes, the reality of what the slaughter of the animal involves is suggested with knife sharpening but the audience is somehow protected from a more graphic depiction and a reminder of what the Islamic sacrifice involves. The two other scenes with a sheep are in a premonitory dream and its reoccurrence in a 'real' scene. The dream shows a shepherd with a flock of sheep: the shepherd in the dream is the father, the son calls him and is not heard, the son is sinking deep in quicksand. The scene conveys great anxiety and brings to mind the dream of Abraham, in a reverse situation as this time the son is dreaming. The third scene is 'real' (part of the reality of the film) and shows a shepherd with his flock at the end of the pilgrimage, before the ritual of the sacrifice is performed. It is dark, the moon disappears behind clouds; there is a suggestion of an eclipse. The Islamic intertextuality this brings to mind is an eclipse coinciding with the death of a young son of the prophet Mohamed, also named Abdallah. Another intertextuality is cinematic, the eclipse scene bringing to mind the eclipse in the crucifixion scene in Pasolini's The Gospel according to Matthew which itself refers to the Christian synoptic gospel account of the crucifixion when darkness covered the land for hours (Matthew 27:45, Mark 15:33, Luke 23:44-45). In Ferroukhi's film, the 'eclipse' scene is very powerful as it comes shortly before the death of the father. The son is led to the body of his father in the crypt where other bodies lie covered with the Islamic shroud. The son performs the Islamic last rites for his father - he learns them by doing them with the group - even if Reda does not speak Arabic and is not interested in performing hajj, in this scene he shows respect for his father's beliefs and a paradoxical way of belonging to the Muslim community through a ritual of separation. The juxtaposition of the sheep with the father - in these three different scenes where the sheep is depicted explicitly - allows a strong juxtaposition of the character of the father with the motif of the sacrificed animal. The ellipsis of the sacrifice of the sheep shifts the sacrifice onto the father who does die in the story, a strong contrast with the two other films in which - like Ismael, Abraham's son - the migrant parent is saved, it is the 'old ways' that are sacrificed. Compared to the other films, it is important to stress that Reda is a young man, older than the 'gone' and older than Zouina's children who are still in primary school; the complexity of Ferroukhi's film focusing on a young adult's journey reflects also a coming of age of Maghrebi-French cinema.

The narratives of all three films highlight the sacrifice of the parent generation for their children. There is a possible convergence between the Christian symbolism of the sacrificial lamb (Jesus) and the figure of the sacrificed migrant parent; this is more emphatic in Ferroukhi's film as the father dies. What appears also is that in these films, the Islamic-Arabic features are reinvented to reach a constructed Maghrebi-French audience. The Abrahamic motif of the sheep is reinvested with a Christian-derived symbolism. The features of the Islamic ritual are somehow translated and sublimated into syncretized Islamic-Christian representations in which the migrant father/mother sits in the paradigm of Christ, and the Abraham narrative reaches out to both Islamic and 
Christian representations. The ritual of the sacrifice is itself ancient and already syncretic; nevertheless, this might be interpreted as a remarkable example of how religious identity is renegotiated to guarantee coexistence in a multi-cultural society.

In French secular society, the feast of the sacrifice of the sheep had first to be recognized and then redefined so that it would fit in within the multicultural space and French regulations. For the Maghrebi communities this has moved the sacrificial space from the communities into the space of the slaughterhouse. In migration cinema, this also is reinvented and the sacrificial sheep in these three case-studies is an Islamic-Christian representation of the migrant parent.

\section{CITED FILMS}

Fatih Akin (2008) Auf der anderen Seite (The Edge of Heaven) (116 mins), Anka Film/Corazón International/Dorje Film/Norddeutscher Rundfunk Germany, Turkey, dist. The Match Factory.

Yamina Benguigui (2001) Inch'Allah Dimanche (96 mins), Bachir Deraïs, Philippe Dupuis-Mendel, France, Algeria, dist. ARP Sélection, Divisa Home Video (Spain), Film Movement (USA)

Mehdi Charef (1985) Le Thé au harem d'Archimède (110 mins), Costa-Gavras, Michèle Ray-Gavras, France

François Dupeyron (2003) Monsieur Ibrahim et les fleurs du Coran (95 mins), ARP Sélection, France 3 Cinéma, dist. ARP Sélection (all media)

Ismaël Ferroukhi (2004) Le Grand Voyage (108 mins), Humbert Balsan, France, Morocco, Bulgaria, Turkey, dist. Pyramide Distribution

Abdellatif Kehiche (2007) La Graine et le mulet (Couscous) (151 mins), Claude Berri, France, Tunisia, dist. Pathé Distribution

Pier Paolo Pasolini (1967) Il vangelo secondo Matteo (The Gospel According to St. Matthew) (137 mins), Alfredo Bini, Italy, dist. Titanus Distribuzione S.p.a.

\section{REFERENCES}

Begag, A. 1986. Le Gone du Chaâba. Paris: Éditions du Seuil.

Cadé, M. (2004). L'Ecran bleu. Perpignan: Presses universitaires de Perpignan.

Carpenter-Latiri, D. 2003. 'Représentations de la femme migrante dans 'Inch'Allah dimanche' de Yamina Benguigui'. Web Journal of French Media Studies, December 2003 Available from: doi: ISSN 1460-6550. 
Charef, M. (1983). Le Thé au harem d'Archi Ahmed. Paris: Mercure de France.

Dioceserabat.org. 2014. Le Sacrifice d'Abraham dans le Coran et dans la Bible| Diocèse de Rabat. [online] Available at: http://www.dioceserabat.org/?q=le-sacrifice-d-abrahamdans-le-coran-et-dans-la-bible [Accessed: 13 Mar 2014].

Emery, M. 2004. Azouz Begag's "Le Gone du Chaâba": Discovering the Beur Subject in the Margins. The French Review, pp. 1151--1164.

Felouzis, G. 2003. La ségrégation ethnique au collège et ses conséquences. Revue française de sociologie, 44 (3), pp. 413--447.

Hashmi, T. and Malik, A. 2010. Hajj \& Umrah made easy. Birmingham: Al-Hidaayah Publishing \& Distribution Ltd.

Higbee, W. 2013. Post-Beur cinema. Edinburgh: Edinburgh University Press.

Ina.fr. n.d. Dépôt d'une gerbe à la femme du soldat inconnu - Elles@centrepompidou Ina.fr. [online] Available at: http://fresques.ina.fr/elles-centrepompidou/fichemedia/ArtFem00101/depot-d-une-gerbe-a-la-femme-du-soldat-inconnu.html [Accessed: 14 Mar 2014].

Kanafani-Zahar, A. 1997. Le religieux sublimé dans le sacrifice du mouton: un exemple de coexistence communautaire au Liban. L'Homme, 37 (141), pp. 83--100.

Lacoste-Dujardin, C. 1985. Des mères contre les femmes. Paris: La Découverte.

Maamar, H. S. 1998. Algérie. Les ‘bestiaires sacrificiels'. In: Brisebarre, A. eds. 1998. La Fête du mouton. Un sacrifice musulman dans l'espace urbain. Paris: CNRS, pp. 207-224.

Mahdi, M. 2003. Maroc. Se sacrifier pour sacrifier : prescription sociale et impératifs religieux. In: Brisebarre, A. eds. 2014. La fête du mouton. Paris: CNRS, pp. 283-315.

Schmitt, E. 2001. Monsieur Ibrahim et les fleurs du Coran. Paris: Albin Michel. 